\title{
Den unge Grundtvig som litteraturteoretiker
}

Forelesning ved Universitetet i Bergen under Danske Dage i oktober 1966.

\section{Av Sigurd Aa. Aarnes}

Når Danmark i denne uken skal presenteres i Bergen, er det ikke urimelig å ta Nikolai Frederik Severin Grundtvig med. Som få andre har han preget dansk åndshistorie. Med sine ca. I6oo salmer og salmeoversettelser og sin kamp for kirkelig frihet har han satt sitt uutslettelige stempel på den danske folkekirke. Han har preget den danske skole med sin folkehöyskoletanke. Som lyriker har Gr. - selv om man ser bort fra hans salmediktning - en plass i dansk litteraturhistorie ved siden av nasjonens störste diktere. Han er mytolog og filolog, psykolog og erkjennelsesteoretiker, litteraturkritiker og kulturfilosof, teolog og predikant, historiker og folklorist, politiker og mye mer. Han er en av Danmarks siste polyhistorer. Utenfor realfagene og musikken vil det være vanskelig å finne et fagområde som han ikke har streifet i sitt gigantiske forfatterskap. Som menneske er han - for å sitere en dansk Gr.forsker - »vel en af de mærkeligste, der har levet $\left.^{1}\right) \ll$.

Det ligger noe av en skjebnens ironi i dette at Gr. - det levende ords talsmann - som ingen annen dansk forfatter har sittet bundet til sitt skrivebord og de döde skrifttegn. »Jeg maa skrive eller ikke leve «, heter det alt $\mathrm{i}$ en av dagbökene fra ungdomsårene ${ }^{2}$ ). I nesten 70 år har hans penn vært i aktivitet flere timer hver dag. Resultatet har blitt et trykt og utrykt forfatterskap av så enorme dimensjoner at vi i virkeligheten först med det store registreringsarbeide som har vært gjort etter den 2. verdenskrig, har fått full oversikt. Det har vært regnet ut at hvis hele forfatterskapet, trykt og utryk, skulle samles $\mathrm{i}$ en utgave, ville den bli på »langt over 30 ooo tættrykte

I. Grundtvigs erindringer og erindringer om Grundtvig. I udvalg ved Steen Johansen og Henning Höirup, Kbh. I 948, s. I I.

2. Nik. Fred. Sev. Grundtvigs Udvalgte Skrifter ved Holger Begtrup, I. bind, Kbh. 1904 (forkortet US. I), s. 64 . 
Sider « eller 1 20-I 30 store bind ${ }^{3}$ ). Jeg kan nevne at Steen fohansens bibliografi over Gr.'s trykte arbeider er på 4 bind med i alt ca. I 300 sider, mens den registrant over de utrykte papirene, som nylig er utarbeidet av danske Gr.forskere, er på 30 bind.

Det sier seg selv at ikke alt kan være like godt innenfor et forfatterskap av slike dimensjoner. Det står ikke til å nekte at det over store deler - særlig av den eldre Gr.'s prosaforfatterskap - er noe rutinemessig stivnet, noe formelfast, en trettende gjentagelse av de samme yndlingsideer med de samme ord, en nesten utålelig selvbevisst avfeiing av alle innvendinger og motforestillinger og en nesten monoman ordrikdom $^{4}$ ). Gr. er ikke av de forfattere som sparer sin leser. Som regel skal man i prosaskriftene være med på hele tankeprosessen. Gr. tenker med pennen $\mathrm{i}$ hånden - suverent ubekymret om trykningsutgifter og leserens tid. Men så - midt i det tilsynelatende örkenlandskap - hender det at vi heves opp til det vide utsyn og det tales til oss om menneskelivet av en röst som er ingen annen enn Gr.s og ut fra en innsikt som bare er hans.

Det sier seg selv at skal en tale meningsfylt om Gr., må man begrense seg - tidsmessig, genremessig eller motivmessig. Jeg hadde tenkt å bruke denne timen til å tale litt om den unge Gr. som litteraturteoretiker. Det var han nemlig også. Spredt omkring i hans förste trykte og utrykte forfatterskap finnes det brokker av en diktningens teori av kristen og platonisk farve. Vi kommer altså til å beskjeftige oss med spörsmål som: Hva er - etter Gr.s oppfatning - diktningen? Hvordan blir den til? Hvilken sammenheng er det mellom diktningen og andre menneskelige åndsaktiviteter?

Med den unge Gr. mener jeg her Gr. i rundt regnet det förste tiår av hans forfatterskap. Avgrensningen skulle være forsvarlig. I disse årene utformes de grunntrekk ved Gr.s poetikk som alltid senere ligger fast. Sin förste artikkel av noen betydning får han trykt da han er en 23 år gammel huslærer på godset Egelökke på Langeland i i 8o6. Via noen år som stipendiat ved Valkendorfs kollegium i Köbenhavn I 8o8- I I og to år som personellkapellan hos sin far i barndomshjemmet i Udby på Syd-Sjælland I 8 I I-I 3 ender denne förste perioden av hans forfatterskap midt i Gr.s 7 »magre år «, da han i I8I 3-20 lever uten embete som en slags free lanceskribent, tidsskriftutgiver og oversetter i Köbenhavn. De to store begivenheter i Gr. liv i disse ti

3. US. I, forordet, og Kaj Thanning: Menneske först - Grundtvigs opgör med sig selv, Kbh. I 963 , bind I, s. Io.

4. Jfr. Ejnar Thomsen i Grundtvig-Studier I 952, s. 87. 
förste årene av hans forfatterskap er hans gjennombrudd til et selvstendig åndsliv ı 805-6 på Egelökke og hans kristelige omvendelse i desember I 8ı. Også for Gr.s poetikk har disse to begivenhetene hatt avgjörende betydning.

Ved siden av historisk lesning har »de skjönne Videnskaber«, som Gr. med I 7oo-tallets terminologi kaller det i sin dagbok, vært hans förste åndelige interesse. Som dikter og litteraturteoretiker går han som rimelig kan være - i lære hos det 8 . århundres dansk-norske klassikere. Han nevner selv i sine dagböker P. A. Heiberg, Rahbek, Baggesen og Det norske Selskabs menn - Wessel, Rein, Edvard Storm $^{5}$ ). En særlig rolle synes Holberg å ha spilt i Gr.s tidligste lesning. Så vidt jeg kan se, er ingen forfatter sitert så ofte i Gr.s dagböker för Egelökke-tiden som Holberg. Våren I 804 har den 2 I årige teologiske kandidat öyensynlig en ren Holbergraptus: Han ekserperer Peder Paars og de latinske levnetsbrevene og oversetter 67 av Holbergs latinske epigrammer til dansk ${ }^{6}$ ). I det hele skulle jeg tro at Holbergs påvirkning på Grundtvig som begynnende dikter er verd en nærmere undersökelse.

Vi merker innflytelsen fra det I8. århundre i Gr.s förste dikteriske forsök - i de nokså ugrundtvigske genrer han etter tur velger: den rimede komiske fortelling (mönster: Wessel, Baggesen), komedien (Holberg, P. A. Heiberg), den historiske prosafortelling (Ewald, Suhm) - ja, selv drikkevisen (Rahbek). Det virker - som han etter Holbergs og I 70o-tallets mönster - vil produsere seg $\mathrm{i}$ alle genrer. Kjennskapet til det I8. århundres poetikk er også tydelig når Gr. i sine förste forsök som litteraturkritiker legger så stor vekt på hvilken genre det litterære verk tilhörer, eller når han i noen berömte dagboksnotater på Egelökke 9. og I9. september I805 distanserer seg fra I 7oo-tallets mest alminnelige definisjoner av poesi, som han innrömmer han selv tidligere har hyllet: »Jeg betragtede Poesien ... som den, der skal muntre Sindet, vække gode Fölelser, og overhovedet være et af Moralens Vehikler $\left.\ll^{7}\right)$.

5. US. I, s. I5, 29, Grundtvigs erindringer, s. 3 I .

6. US. I, s. 50 og 54. Jfr. Henning Höirup: Menneske först ... En GrundtvigHolberg Studie. Vartovbogen 1947, s. I 24-157. K. E. Bugge: Grundtvigs Holberg-studier I804, Guldalderstudier, Festskrift til Gustav Albeck den 5 juni I 966 , s. I-9.

7. US. I, s. $8 \mathrm{I}$ og Flemming Lundgreen-Nielsen: N. F. S. Grundtvig. Skæbne og forsyn, Kbh. I 965 , s. I 5 og 39 . 
Nå, sier Gr. i det samme dagboksnotat, har han imidlertid fått en »höjere« oppfatning av poesien: »Poesien er alt det, som bærer det Eviges Præg «, mens »Prosa er Alt det, hvis Tendents er blot endeligt $\left.\ll^{8}\right)$. Det er saklig - om ikke ordrett - en gjengivelse av den definisjon av poesien Gr. kan ha hört to år tidligere under sin fetter, Henrik Steffens', universitetskateter i Köbenhavn: »Prosa kalder jeg, hvad som nedværdiger selv det, som bærer det Eviges umiskjendelige Præg, til et blot Endeligt, Poesie det, som selv i det Endelige finder Præget af det Evige $\left.\ll^{9}\right)$.

Det er vanskelig i dag å sette seg inn i hvilken umåtelig sprengkraft det har ligget $\mathrm{i}$ disse ordene for de unge som satt under Steffens' kateter. Ved siden av Schack Staffeldts diktning, Henrik Steffens' forelesninger og Oehlenschlägers »Digte« 1803 betyr Gr.s dagboksnotater på Egelökke fra 9. og ı. september 1805 romantikkens gjennombrudd i Danmark ${ }^{\mathbf{1 0}}$ ).

Sett $\mathrm{i}$ vår sammenheng markerer dagboksnotatene at epigonfasen i dikteren og kritikeren Gr.s liv er slutt. Han går ikke lenger i lære hos det I8. århundre. Diktningen er ikke lenger en av »de skiönne Kunster «, ornament og tidsfordriv, et middel til å utmerke seg fremfor jevnaldrende. Nå er diktningen blitt det ramme alvor, en höyeste verdi på linje med religionen. Som i religionen ser han i diktningen en kontaktmulighet med »det Evige«. Poesi er alt det som bærer det eviges avglans. Det guddommelige »udgör Poesiens Sjel«. Poesien og det transcendente perspektiv på mennesket hörer ulöselig sammen.

$\mathrm{Ja}$, for den unge romantisk påvirkede Gr. blir poesien likefrem et bevis for at det må eksistere en usynlig åndelig virkelighet over den vi kan gripe med våre sanser. Enten måtte nemlig dikteren gå skaperen i næringen og selv skape denne höyere virkelighet, ellers må den fullkomne skjönnhetverden vi möter i diktningen, avspeile en oversanselig realitet som ellers ikke er tilgjengelig for oss på annen måte

8. US. I, s. I 79.

9. Henrik Steffens: Indledning til philosophiske Forelæsninger i Köbenhavn 1803 ved B. T. Dahl. Kbh. I905, s. I I I.

Iо. Av hensyn til den pedagogiske forenkling trekker jeg ikke her inn William Michelsens påvisning av at »den krise, der förte til det romantiske gennembrud, var begyndt næsten eet år för forelskelsen i Constance Leth. Det er Gr.s syslen med Holberg og Addison i foråret i 804, der har genkaldt forskjellige ytringer fra Steffens's to forelæsningsrækker ... og de spekulationer, der udvikler sig heraf, er det egentlige udgangspunkt for krisen « (Tilblivelsen af Grundtvigs historiesyn, Kbh. 1954, s. 26 I ). 
enn gjennom religionen. For Gr. blir poesien mer en bestemt holdning og forhold til det usynlige enn et kunstnerisk uttrykksmiddel. Det poetiske i mennesket består i »Beskuelsen af det Jordiskes underordnede Forbindelse med det Himmelske«, poesien er menneskets $»$ Higen ud over det Synlige«. »Der er i Mennesket en vemodig Fölelse af alt det Synliges Forfængelighed, en Længsel efter fuld Tilfredstillelse, efter en rolig, harmonisk Tilværelse, en Ahnelse af noget Usynligt, som er evigt og harmonisk, en Længsel efter at finde, at beskue, at forenes med det. Dette hellige, uudsigelige Noget er det Poetiske hos Mennesket...«"11).

I dette på en gang kristne og platoniske »overlys« kom Gr. alltid senere til å se på diktningen. Satsen fra dagboksopptegnelsen i 1805 om at »Poesien er alt det, som bærer det Eviges Præg«, ligger under alle hans senere tanker om diktningen. Diktningen er her for å minne oss om at vi er evighetsvandrere med et evighetsmål og for å tegne dette mål for oss i den skjönneste skikkelse. Diktningen har derfor aldri egenverdi for Gr. Den interesserer bare i den utstrekning den knytter kontakten med og avspeiler det evige. »Det æstetiske interesserer udelukkende Gr., forsåvidt som det er forbundet med det ideologiske . . . Poesien må underordne sig sandheden, den höjere virkelighed, om denne så hedder religion eller historie«. Skjönnhet er for Gr. ensbetydende med sannhet ${ }^{12}$ ). »L'art pour l'art « er ikke noe for ham. Hvis man ikke forstår eller kan sette seg inn i dette uartistiske ved Gr.s fundamentale livsholdning, vil hans poetikk alltid bli en lukket bok for en.

Satsen om at »Poesien er alt det, som bærer det Eviges Præg«, ble selve nökkelordet for Gr. Med det hadde han på en gang vunnet frem til et eksistensielt forhold til diktningen og funnet en samlende formel som han kunne vurdere sin egen og andres diktning etter. I samme grad som evighetsperspektivet på menneskelivet fremtrer i diktningen, i samme grad er den verdifull, mener Gr.: De sanne diktere er alltid »det Eviges Digtere«. Gr.s skrifter er fulle av lovprisninger og forkastelsesdommer over andres (og egen) diktning på grunnlag av dette kriteriet.

Og i de samme månedene på Egelökke som han finner satsen om

I I. Sitert etter Sigurd Aa. Aarnes: Historieskrivning og livssyn hos Grundtvig, Bergen-Oslo i 96 I, s. I 20-I 2 I.

I 2. Flemming Lundgreen-Nielsen, s. 55, 52, jfr. I 74 og Grundtvig-Studier 1952, s. 83 . 
at poesien er avglansen av det evige, er han selv blitt dikter, virkelig dikter og ikke bare en I 7oo-talls epigon. Som Jatgeir skald i Ibsens »Kongsemnerne « har Gr. på Egelökke fått sorgens gave å bli dikter på. Fra de aller förste ukene på Langeland våren $\mathrm{I} 805$ vet han at han er fanget inn av håplös kjærlighet til herregårdens frue, Constance Leth, sin elevs mor. I denne situasjon blir romantikkens idealistiske filosofi - Fichte og Schelling - og först og fremst den norröne mytologi den unge Gr.s redningsplanke. Hva gjör det egentlig at han ikke kan få Constance selv, når hun med sin skjönnhet og sin sang har vakt til live hos ham »Ahnelsen « av det evige? I sublime öyeblikk av dikterisk inspirasjon föler han seg höyt löftet over sin situasjon som ulykkelig elsker. Det er en kompensasjonsmekanisme vi kjenner godt fra Gr.s samtidige, Wergeland: Når man ikke kan få de höyst reelle småpiker Emilie Selmer, Hulda Malthe eller Elise Wolff, så kan man finne erstatning og mer enn det med den diktede Stella i den himmelske salighet! Særlig söker Gr. som nevnt kompensasjon i den norröne mytologien, for hvor finnes det en klarere avglans av det evige enn $i$ våre fedres gudelære? I gullalderen ved tidenes begynnelse vandret gudene på jorden, hadde Steffens hevdet i sine forelesninger ${ }^{13}$ ). Våren 1807 unnfanger Gr. i en ekstatisk »Asarus « det syn på den norröne mytologi som han först nedfeller i den merkelige artikkelen »Om Asalæren« i mai-nummeret av Ny Minerva, og som han faktisk dikter på helt frem mot det kristne gjennombrudd i desember I 8 I 0 .

Som aldri hverken för eller senere satser Gr. i disse årene på diktningen som sin hovedbeskjeftigelse. Han vil være »nordisk Digter«, dramatiker med »Kampspil«, dramatisert historie som spesialitet (»Optrin af Kæmpelivets Undergang i Nord «, I 8o9, »Optrin af Norners og Asers Kamp«, I8I I ). Etter at han er kommet tilbake til Köbenhavn fra Langeland våren 1808, kaster han seg öyeblikkelig ut i hovedstadens litterære liv som kritiker og lyriker, innynder seg hos Baggesen og arbeider bevisst på å oppnå en posisjon på det danske parnass som den tredje store ved siden av denne og Oehlenschläger. Da blir spillet med ett slått i stykker for ham. I desember i8 10 kastes han ut i en alvorlig nervekrise og må reise hjem til sine foreldre i Udby prestegård ${ }^{14}$ ).

13. Steffens, op. cit. s. 94 .

I 4. Gustav Albeck: Omkring Grundtvigs Digtsamlinger, Kbh. I955, s. 58-62. 
Med denne nervekrisen, der Gr. bryter sammen i en luthersk opplevelse av det salmen kaller »fordervelsens avgrunn i meg « og reservasjonslöst stiller sitt liv i kristendommens tjeneste, oppstår en ny situasjon for hans diktning. Han er ikke lenger nordisk dikter, men $» k r i s t e n$ Skjald«. Ideologisk dikter hadde han nok vært like fra det åndelige gjennombruddet på Egelökke i i 805, men han hadde ikke tidligere stått i en så absolutt ideologis tjeneste som den lutherske ortodoksi han identifiserer seg med fra I8Io. I hans sinn strides nå to makter. På den ene siden står den romantiske kunstfilosofi, som ser diktningen som en höyeste verdi - det eviges avglans i det timelige. På den andre siden den lutherske ortodoksi med sitt krav på å akte alt for skarn i forhold til kunnskapen om Kristus Jesus og ta enhver tanke til fange under troens lydighet. Bör han ikke nå - som mannen i Jesu lignelse - selge alt, også sin dikterdröm, for å vinne den kostelige perle? Vi kan se hvordan han har lekt med tanken: Han holder ikke lenger ut »noget Arbeide, hvor jeg skulde glemme min Frelsers Pris og hans Ophöielse... hvorledes skulde Noget som ei hörer ham til, eller leder til ham kunne begeistre mig mere? ${ }^{15}$ ). Og hvis det nå likevel er tillatt for den kristne å beskjeftige seg med verdslig diktning, hvordan skal han legitimere dette teologisk? Eller med andre ord: Hvordan skal han få plassert den romantiske kunstfilosofi han hadde sluttet seg til i I805, på en kristelig formel?

Gjennom flere år fra i 8 I og utover tumler Gr. med disse spörsmålene - ja, på en måte ble han vel aldri ferdig med dem. De hører med som et ledd i det store gjennomgangstema hos Gr. om forholdet mellom det kristelige og det menneskelige. Det er under denne kampen Gr.s kristne poetikk litt etter litt vinner form: Vi skal se hvordan utgangspunktet er den platoniske formel fra Steffens om poesien som avglansen av det evige, men hvordan han omtolker denne formel i kristelig retning og spenner den inn i et nett av teologiske kontaktpunkter.

Dokumentasjonsmateriale er - som nesten alltid hos Gr. - meget stort. Jeg nevner her som noe av det viktigste forordene til diktsamlingen »Saga《 og til »Optrin af Norners og Asers Kamp《 fra henholdsvis november og september I8I I. Til dette kunne man föye det praktfulle »Fortaleriim《 til Roskilde-Saga fra I8I4 - et av Gr. beste kunstfilosofiske læredikt, og en rekke utrykte utkast fra de förste årene

I 5. Sitert etter Lundgreen-Nielsen, s. I 34, I 82. 
etter omvendelsen med titler som »Om Poesie, Konst og Vidskab《, »Om Poesi «, »Om Poesi og Historie« (samlet i fsc. I 59-I64 i Gr.arkivet på Det Kgl. Bibliotek i Köbenhavn). Flere av utkastene er forarbeider til den store kunstfilosofiske avhandlingen »Om Aabenbaring, Konst og Vidskab « i 3. bind av tidsskriftet Danne-Virke, I 8 I 7. Viktige dokumenter er også Verdens-Kröniken av I8ı4, Gr.s kristelige kommentarer i den store retrospektive diktsamlingen $\gg$ Kvædlinger « fra I8I 5 og en preken »Om det österlandske Billedsprog《 i 2. bind av Gr.s Söndags-Bog fra 1827 - for her bare å nevne noe av det viktigste ${ }^{16}$ ). Innenfor Grundtvigforskningen må man först og fremst söke til Albecks, Lundgreen-Nielsens og Toldbergs grunnleggende arbeider om dikteren Gr.

Det man kanskje först vil legge merke til, om man fordyper seg i Gr.s forskjellige uttalelser om diktningen etter i8ı, er hvor godt han utnytter de få tilknytningspunkter for en poetikk som finnes i Bibelen. Jeg skal gi et eksempel på hvordan denne konvertering fra en romantisk til en kristen formel foregår i praksis. I forordet til »Optrin af Norners og Asers Kamp« fra september I8 I f finner Gr. som vi skulle vente - det först nödvendig å forklare hvordan han, en kristen mann, kan bruke tid og krefter på et verk om de hedenske, norröne guder. Han har vært »hardtad tilsinds at brænde det hele Eventyr, da den afgudiske Snak, selv i Hedningmund, tyktes mig forargelig, og al verdsligt Skjaldskab en Sjæls Overdaad, der ligesom dens legemlige Frænde svækker og slöver, i det den kildrer og gotter«. At han likevel ikke har kassert det hele, har flere årsaker:

Saasandt som Poesien er, hvad Evald, og hver kristelig Digter, har fornummet, den sande Levning af det forlorne Gudsbillede, maa vi have Ærbödighed for alle de Oldtidskvad, der löfte sig mod det Himmelske foroven, og prise det Guddommeliges Spor herneden; alle disse Ting virkede kraftelig den ene og samme Aand, hvorom vi selv have den hellige Povels Vidnesbyrd, der han i Athenen anförer de græske Skjaldes Udsagn om Menneskets Liv i Gud og Slægtskab med ham. Den samme Aand, som talte nærværende gennem Jödernes Profeter, har da ogsaa ladet Nordens Skjalde höre sin Röst; vel löd denne kun svagt for dem, som fra det Fjerne, og onde Aander forvirrede Tonerne i Luften; men for et Öre, der har lyttet til Guds klare Stemme i de hellige Skrifter, er den himmelbaarne Klang mærkeligere, end den var for hine gamle Skjalde selv, ligesom den hellige Povel forstod langt bedre, hvor-

16. Jfr. oversikten i kapitlet »Grundtvigs egne udtalelser«, s. I5-3 I i Helge Toldberg: Grundtvigs symbolverden. 
ledes vi ere, leve og röres i Gud, end de græske Digtere og Nutidens afgudiske Pantheister ${ }^{17}$ ).

I steden for den platoniske bestemmelse av poesien i dagboksnotatet fra $\mathrm{I}^{80} 5$ settes poesidefinisjonen i dette avsnittet med en gang på teologisk formel: Poesien er »den sande Levning af det forlorne Gudsbillede«. Da mennesket, skapt i Guds bilde, falt i synd, ble det likevel tilbake en rest av gudsbildet. Denne menneskets iboende »Higen ud over det Synlige « er det poetiske i mennesket, sansen for poesi og evnen til å skape poesi. Også de »Oldtidskvad «, den diktning som ble til för kristendommen eller utenfor den kristne kulturkrets, er altså ytringer av gudsbildet i mennesket. I disse »Oldtidskvad« ser Gr. hvordan mennesket strekker seg i lengsel mot »det Himmelske foroven « og leter etter den naturlige gudsåpenbaring i naturen og historien. Det underforståtte bibelsted synes å være Rom. I,20: 》Hans usynlige vesen ... er synlig fra verdens skapelse av, idet det kjennes av hans gjerninger«. Viser ikke selv Paulus i sin tale på Areopagos til denne naturlige gudsåpenbaring hos de greske diktere (Ap. gjern. I 7,28)? Men når Gud kunne tale gjennom ikke-kristne greske diktere, må han også ha kunnet tale gjennom de norröne skalder, slik han tydeligst talte gjennom de förkristne jödiske profeter. Den norröne mytologi og diktning blir vårt gamle Testamente.

Flere av de bærende grunntanker i Gr.s kristelige poetikk finnes i dette sitatavsnittet. Vi möter her minst tre viktige teologiske tilknytningspunkter for Gr. poetikk: Selve poesibegrepet knyttes - som vi har sett - til den teologiske lære om »imago dei«, gudsbildet i mennesket som overlever syndefallet. I sammenheng med dette bestemmes diktningen som en naturlig gudsåpenbaring. I hele sin fylde möter vi Gud bare gjennom Jesus Kristus, men ved siden av dette kan Gud på mer ufullkommen måte erkjennes gjennom sitt skaperverk og gjennom historien. Her hörer diktningen hjemme. Det er »Poesiens Natur«, som Gr. skriver et annet sted, med David å utbryte: »Himlene forteller Guds ære, og hvelvingen forkynner hans henders gjerning « (Salme 19, 2 $)^{18}$ ).

Det tredje og kanskje viktigste teologiske tilknytningspunktet for Gr.s poetikk finner vi i den parallell han i sitatavsnittet trekker mellom den greske og norröne dikter p. d. e. s. og den jödiske profet p. d.

I 7. US. I, s. $55^{2}$.

I8. Sitert etter Aarnes, s. 120. 
a. s. I en rekke sammenhenger har Gr. tatt opp forholdet mellom den israelittiske profeti og diktningen utenfor Israel. Er diktning og profeti fenomener av samme slag eller er det to forskjellige virksomheter? Problemstillingen har Gr. nærmest fra Herders bok »Vom Geist der erbräischen Poesi $\ll$, der profetene oppfattes som diktere ${ }^{19}$ ). Gr. behandler spörsmålet bredest i Verdenskröniken av ı8I4. Når han her kommer til de gammeltestamentlige profeter og skal forklare sine lesere hva en profet er, går han omveien om dikteren. Skal vi i dag danne oss et bilde av hva den gammeltestamentlige profetaktivitet var, kan vi ikke komme saken nærmere enn ved å se på dikteren. Den »Inspiration« eller »Indaandelse« som var »over og i Propheterne «, kan stundevis også i dag beröre dikteren som »Begeistring « eller »Beaandelse«. Profetene var »gudfryktige Skjalde i Poesiens blomstrende Alder og hos det mest poetiske Folk $\left.\ll^{20}\right)$.

Hos profeten og dikteren foregår, hevder Gr., strukturelt sett den samme prosess: Först kommer både hos profeten og dikteren synet. Synet de skuer, blir inngitt dem utenfra og tilhörer en åndelig virkelighet som ikke er tilgjengelig for det fysiske syn. Det dikteren og profeten har sett, setter deres fölelser $\mathrm{i}$ bevegelse, og det våkner hos dem begge en drift etter $̊$ »fængsle de aandige Billeder $\mathrm{i}$ billedlige Ord «. Gangen i den poetiske og profetiske skaperakt blir da: åndelig syn - inntrykk i fölelsen - språklig uttrykk. Terminologien kan skifte noe. Snart heter det »Virkning indad《 og »Virkning udad«, snart »Syn« og »Virken efter Syn«, snart tales det om å »indbilde Synet i sig og ... indbilde det i Andre«, snart heter det »Syn og Sang«, snart poesi og kunst ${ }^{21}$ ).

Når Gr. skjelner så skarpt mellom synsfunksjonen og avpregningsfunksjonen, er det blant annet fordi han ikke ser de to funksjoner som likeverdige. Synet er viktigere enn synets språklige avpregning, eller med andre ord: diktningens innhold er viktigere enn den form diktningen fremtrer i. Motsatt grekernes dyrkning av formen og det språklige uttrykk er den jödiske profeti det all kristen diktning etter Gr.s oppfatning - burde være: et syn »udsagt i Ord, for sin egen, ei for Skikkelsens Skyld, altsaa i sit uvilkaarlige, konstlöse Ud-

19. Michelsen: Tilblivelsen osv., s. $330 \mathrm{f}$.

20. Sitert etter Aarnes, s. 198. Gr. kan imidlertid også - ut fra profetienes enestående innhold - understreke forskjellen mellom den gammeltestamentlige profeti og all diktning. Se Aarnes s. I98-r 99, $307 \mathrm{f}$.

2 I. Jfr. Albeck s. 36-37, Toldberg s. 227-236 og Aarnes s. I89 f. og $252 \mathrm{f}$. 
brud $\left.\ll^{22}\right)$. Det er »meget bedre at Formen revner, end at Synet brister $^{23}{ }^{23}$. Derfor mener Gr. at en ikke-kristen dikter lettere når formens mesterskap enn en kristen. Han bruker her et bilde: Den kristne dikter arbeider i edelsten. Ville man slipe av en kant av et så kostbart materiale for formens skyld? Annerledes for den som arbeider i ler. Han har ikke slike hensyn å ta. Alt blir likevel vakrere enn leret $\operatorname{selv}^{24}$ ).

Det som först og fremst har fengslet Gr. i hebraisk poesi, eller kanskje rettere sagt: i Herders oppfatning av den hebraiske poesi, er likevel dens karakter av billedtale. Hebraisk bruker samme ord for syn og sang! $\left.{ }^{25}\right)$. Allerede $\mathrm{i}$ forordet til diktsamlingen $\gg$ Saga《 fra november I8I I peker Gr. på at Bibelen i sin billedtale har gitt et eksempel som er bindende for alle diktere til alle tider. Diktning er billedsyn og billedtale.

Gr. tar i dette forordet först opp den pietistiske misforståelse at den kristne skal »tale om Guds Ord « i den forstand at hans tale skal være et blott og bart ekko av bibelordet. All vår tale skal nok utgå fra Gud, men den skal vende tilbake til ham »paa adskillige Veie«. Her er de gammeltestamentlige profeter våre beste veiledere: »Hvor vidt flyve ei Job og David og Profeterne, uden at Gud nogensinde bliver borte for dem? « Og, hva med Jesus selv? Med »hvor mange Ting ligner han ikke Guds Rige! forfölger han ikke Ligheden gennem det Döde og det Levende, fra Perlen og Sennepskornet indtil Mennesket; og gennem Menneskets Idrætter fra Hyrdens og Bondemandens Syssel, indtil Kongens Bedrift i Höieloftssale? « Også i sin bruk av billedspråket er da Jesus »vort uoppnaaelige Mönster ... af ham kan vi ... lære, under hvilken Skikkelse Gud aabenbarer sig i Köd ${ }^{26}$ ).

Sitatet peker langt fremover mot den modne Gr.s tanker om billedspråket som det spesifikt kristne språk, slik vi f. eks. möter dem i den praktfulle prekenen fra midten av 1820 -årene $\gg \mathrm{Om}$ det österlandske

22. Sitert etter Toldberg s. 229.

23. US. III, s. 6 I 8.

24. Jfr. Aarnes s. 297. Gr. er også et sted (fsc. I 5 I, 6) inne på at selv den genre en dikter velger, må forståes ut fra hans religiöse standpunkt. En kristen dikter i en 》vantro《 tid vil benytte andre litterære uttrykksformer enn en »vantro《 dikter i en 》troende《 tid! Se Aarnes, note 58 , s. 192.

25. Grundtvig: Kort Begreb af Verdens Krönike, betragtet i Sammenhæng. Förste Bind. I 8 I 4, s. 2 I o, note.

26. US. II, s. 94-95. 
Billedsprog $\left.{ }^{27}{ }^{27}\right)$. Det hörer med til menneskets vesen - hevder Gr. her - at det bare kan oppfatte en åndelig virkelighet i billedlig form.

\author{
Kun under Dunkelheds Gestalt \\ Kan Speil af Stöv afbilde Alt, \\ Hvad Ordet skal udtrykke ${ }^{28}$ ).
}

Slik Kristus i sin gud-menneskelige natur forener det himmelske og det jordiske, og slik mennesket i seg forener både en åndelig og legemlig side, slik smelter i billedspråket det usynlige og det synlige sammen: det guddommelige og det menneskelige, det åndelige og det legemlige. Vi mennesker kan ikke en gang tale om vårt eget indre liv uten å bruke bilder fra den synlige virkelighet. Dette visste Gud. Derfor har han på en særlig måte bundet sin åpenbaring til billedspråket. Billedspråket er blitt »Herrens, og Aandens, Propheternes og Apostlernes Sprog «. Fra sin opprinnelse i Østerland bærer kristendommen med seg billedspråket og kan aldri skilles fra det. Derfor er det på en særlig måte legitimert og helliget for den kristne dikter. Så lenge vi er her, kan vi ikke greie oss uten »Billed-Havet, hvori den Himmel speiler sig, hvilken vi först kan see som den er, naar Troen giver Plads for Beskuelsen Ansigt til Ansigt«. I diktningens billedspråk mötes den synlige og usynlige verden. Å dikte er å skape »Billed-Legemer, hvori det aandelige som er usynligt i sig selv, kan betragtes i en Lignelse med Liv og Lyst«. A dikte er »at sammensmelte Syn og Sang, til et yndigt, skinnende, giennemsynligt, sjungende Billede af Skabningen i sit höieste, aandige Forhold $\ll^{29}$ ).

Kristendommens sannhet er så »höi og dyb《 at den av mennesker bare kan oppfattes som en gåte og betraktes i et speil. Vi kjenner Gr.s salmestrofe om Christus-Riget: Dets gåte er her »et guddoms-ord, som skaber, hvad det nævner «, men engang skal det skje at »hvad troende i spejlet så, skal salige erkjende $\ll^{30}$ ).

Her og flere steder i »Det österlandske Billedsprog « alluderer Gr. til et av de grunnleggende bibelsteder for sin kristne poetikk - apostelen Paulus' ord i I. korintierbrev I3, I 2 om at »nu ser vi i et speil,

27. Grundtvig: Christelige Prædikener eller Söndags-Bog, 2. bind, Kbh. I827, s. 408-424.

28. Sitert etter Toldberg s. 6 I.

29. Grundtvig: Krönike-Rim til levende Skolebrug, 3. utg., Kbh. I875, s. 270 og Toldberg s. 228.

30. Den danske salmebog, $\mathrm{nr} .277$. 
i en gåte; men da skal vi se åsyn til åsyn; nu kjenner jeg stykkevis, men da skal jeg kjenne fullt ut, likesom jeg også fullt ut er kjent«. Gr. ser diktningens historie som en slags fremadskridende erkjennelsesprosess fra lys til lys, fra klarhet til klarhet, til det klimaks da vi skal »se åsyn til åsyn«. I denne prosess er dikteren menneskeslektens seer og speider. Eller som det heter i »Fortaleriim《 til »Roskilde-Saga «:

Fryd dig bævende, o Skjald!

Som dit Kaar er og dit Kald;

Giennem dig sig skal afbilde,

Hvad du saae i Livets Kilde,

Gjennem dig skal i det Brede

Rosenduften sig udsprede,

Du er Livets kaarne Speider,

Du er Herrens Medarbeider ${ }^{31}$ ).

Slik er prosessen beskrevet i en av Danne-Virkeavhandlingene:

»... i Hovedet skulde Synerne fremspringe, indaandes i Hjertet, udbryde i Sang og paakalde Aanden, som atter neddalede i nye og store Syner, hvoraf det ene omfattede og forklarede det Andet, indtil omsider, i Tidens Fylde, Himlen oplodes, og Gud opslog sit evige Paulun hos Menneskens Börn, optagne i Englenes Samfund $\left.\ll^{32}\right)$.

Helge Toldberg har i sin store doktoravhandling om »Grundtvigs symbolverden (Kbh. 1950) vist at speilet hos Gr. er menneskenes måte å motta åpenbaringen på. Som »spejlingen er vort middel til at gribe den evige sandhed i den fattige afglans, som mennesker har mulighed for at tilegne sig«, slik er gåten den form som sannheten möter oss i. Slik speilet går på mottakerfunksjonen, slik går gåten på det syn utenfor ham som dikteren söker å avprege i sin diktning ${ }^{33}$ ).

Når Gr. - som Ibsen - så sterkt fremhever synet som dikterens sans fremfor noen annen, har det sammenheng med hans psykologiske teorier. Gr. deler det menneskelige sanseapparat inn i tre indre sanser »hvis yderste Ender ere udvortes tilsyne«: »Indbildningskraft«, $\gg$ Fornuft $\ll$ og $\gg$ Ahnelse«, som i det ytre manifesterer seg som henholdsvis »Syn«, »Hörelse og »Fölelse«. For Gr. er imidlertid inbilningskraft-syn, fornuft-hörsel og anelse-fölelse ikke likeverdige.

31. US. II, s. 622 .

32. Danne-Virike el. Tidsskrift af N. F. S. Grundtvig, 3. bind, Kbh. I817, s. 277.

33. Toldberg s. $6 \mathrm{I}, 66$. 
Den fornemste sans er den som er rettet mot det usynlige: vår åndelige synsevnen, innbilningskraften, evnen til å skue det oversanselige, diktningens $\left.\operatorname{organ}^{34}\right)$. Gr.s psykologiske teorier er bl. a. så interessante fordi de ser ut til i stor utstrekning å ha blitt til på grunnlag av selviakttagelse. De er - med andre ord - en innfallsport til hans hemmeligste opplevelser i dikterverkstedet. Han har selv opplevet dikterens »Synstime«, vært på forklarelsens berg der det »aander paa hver begeistret Digter «, fölt de »stemte Strænges Rörelse til Klang« i seg. Han har selv - som han skriver i en utrykt avhandling - vært

paa Synets Höi, hvor der er den videste, skiönneste Udsigt i hele Stövets Rige, paa den velsignede Plet hvor Stövet som bedækker de sandselige Ting halv bortviftes af ... Zephyrer, hvor Taagen, som indhyller de Dödeliges Blik, slaaer ned, hvor Skyerne adskilles og lade os skimte Efterskin af den Soel som overstraalede Paradiset, hvis mindste Glimt vidunderlig klarer det sandselige Lys og forgylder hvad vi see til vidunderlige, gaadefulde, indtagende Billeder af det levende Usynlige, $i$ hvis Sal vi indkige, $i$ hvis Selskab vi föle os, saa Aande-Drættet er nær ved at stanses (?), og Hjertet hugger $i$ Livet, hvor vi engang dog glemme Verden og os selv over det som er Meer, hvor vi dog engang kan have en glödende Kind og et funklende Öie, uden ureen Begiæring ${ }^{35}$ ).

Han har selv - som de gammeltestamentlige profeter - vært under synenes tvang:

O! foragt ei denne sære Stemme!

Det er underligt at være Skjald,

Rösterne fra Oven vi fornemme

I det hemmelige Tonefald,

Hvad vi sige, selv vi ikke vide,

Men o vee den Skjald, som vilde stride!

Herren selv maa sine Ord forstaa,

Han har skabt, hvad Skjaldeöiet saae $\left.{ }^{36}\right)$.

Dikterharpen som Gr. - ifölge sine egne ord - etter den religiöse krise »hængde over Herrens Alter«, den rakte Gud »mig selv igen, da han havde indviet den til sin, og med frit Mod griber jeg i de nystemmede Strænge $\left.{ }^{37}\right)$. Det viser hans ca. I6oo salmer og salme-

34. Se Aarnes s. 269 f. jfr. 244-245 med henvisninger.

35. Sitert etter Aarnes s. 309.

36. US. II, s. 432 .

37. US. II, s. 94 . 
bearbeidelser og hans verdslige lyrikk, samlet $\mathrm{i}$ de ni bind »Poetiske Skrifter $\left.\ll^{38}\right)$.

Gr. poetikk har opp til den intensive Gr.forskning satte inn etter den 2. verdenskrig, hört til de oversette områder av hans forfatterskap. Det er i og for seg ikke så underlig. Gr. samlet seg aldri til å skrive noe verk om diktningens teori. Til det har vel hans teoretiske interesse på dette område vært for liten. I diktningen er han praktiker og ikke teoretiker. De grunntrekk av Gr. poetikk, som jeg her har lagt frem, har jeg måttet samle fra uttalelser i en rekke skrifter som egentlig ikke primært beskjeftiger seg med diktningens teori. Det er karakteristisk at Gr. rent estetiske studier for det meste bare foreligger som utrykte kladder. Som så mye annet i dette enorme forfatterskap har Gr. poetikk kommet i skyggen av det som ruver mest $\mathrm{i}$ ettertidens bevissthet: hans diktning, hans teologi og skoletanker. Först med det arbeidet som i löpet av de siste 20 år har været nedlagt på å grave frem igjen, ordne og fremstille Gr. tanker om poetikken, har det blitt mulig å vinne et alment overblikk.

Det skulle ikke være nödvendig å utbre seg om hvor umoderne og utidsmessig Gr. poetikk i dag vil föles for mange. Den ideologiske tilknytning til kristen teologi og Platons idélære vil av mange - ikke minst i Gr. eget hjemland - föles som en tilbakelagt tradisjonssammenheng og en innsnevrende tvangströye. For mange vil Gr. kristne poetikk i dag bare ha kuriositetsverdi som en merkelig gjenganger fra romantikken, noe à la romantisk naturfilosofi, eller som et nytt bevis på hvordan selv en stor dikter kan töve når han skal uttale seg om diktningen - ikke minst når den store dikter samtidig er prest.

Dette nokså alminnelige syn kommer vel f. eks. til uttrykk når Steen fohansen skriver i innledningen til den nyeste antologi av Gr. lyrikk: Gr. »mere specielle nationale eller religiöse anskuelser ... tilhörer historien, men hans poesi lever og vil fortsatt leve $\left.\ll^{39}\right)$. Er ikke denne distinksjon for absolutt? Kan vi trenge inn i Gr.s diktning eller i hans tanker om diktningens teori hvis vi helt overser eller bagatelliserer det

38. N. F. S. Grundtvigs Poetiske Skrifter. Ved Svend Grundtvig, G. F. Brandt og Georg Christensen I-IX. Kbg. I 880-1 930.

39. Udvalgte Digte af N. F. S. Grundtvig. Med indledning og noter af Steen Johansen. Hans Reitzels Serie. Kbh. I963. 
ideologiske engasjement som for ham selv er hovedsak og inspirasjonskilde?

Jeg skal ikke nekte at det gjör et visst inntrykk på meg når jeg med en slik uttalelse in mente leser et foredrag om »Diktningens ord: Mythos og logos $\ll^{40}$ ) fra 1960 av Wolfgang Schadewaldt, professor i gresk språk og litteratur og »Nachleben der Antike« ved universitetet $\mathrm{i}$ Tübingen og en av forgrunnsskikkelsene innenfor tysk humanisme $\mathrm{i}$ dag. Jeg finner her en oppfatning av diktningen som bortsett fra den teologiske innkledning - ligger meget nær Gr. og romantikken. Det er vel i og for seg ikke så merkelig, for romantikken, som inspirerte Gr., betyr en av de store Platon-renessanser i europeisk åndshistorie.

For den greskinspirerte Schadewaldt - som for Gr. - er diktningen syn: »Diktningen utspringer av hint like sanselige som åndelige syn, som $\mathrm{i}$ den daglige omgangsverden innfanger en egentligere verdens bærende og grunnleggende forhold og sammenheng. Diktningen er i sin opprinneligste og samtidig höyeste kraft en slags seerkraft for det som $\mathrm{er}$ «. Som Gr. skjelner mellom den egentlige dikter, som er seer, og den uegentlige, som bare er kunstner, slik skjelner Schadewaldt mellom diktning p. d. e. s. og talekunst eller retorikk p. d. a. s. Forskjellen er at talekunsten ikke springer fram av »noe slags syn, men av en ... forstand på verden «, mens dikteren er en seende. Som Gr. oppfatter Schadewaldt diktningens mytiske billedspråk som det opprinnelige. Det var der för logos, vitenskapens entydige språk, ble skapt. Dikteren taler altså menneskets opprinnelige tungemål. Han benytter ikke - som vitenskapsmannen - begrepet, men lignelsen, bildet. I diktningen skal ikke ordet - som i vitenskapen - betegne noe, men det skal bety noe. Parallellen er klar til Gr. skjelning mellom den hebraiske diktning, som dyrker myten og billedspråket, og grekerne som dyrker klarheten, logos, det betydningsmessig avgrensede, entydige ord.

Schadewaldt hevder at vår situasjon $\mathrm{i}$ dag er den at diktningens mytiske språk lever videre $\mathrm{i}$ et slags »indre eksil«, trengt opp i et hjörne av det altdominerende vitenskapelige denotasjonsspråk, som via de moderne massemedia er $\mathrm{i}$ ferd med å erobre hele verden. Hvis

40. Foredraget er trykt i oversettelse i Litteraturforståelse. Diktning og kritikk i serien Idé og tanke, Oslo I96I, s. I69-19o. Jfr. Wellek and Warren: Theory of Literature, London 1955, s. 195. 
det er riktig - som Schadewaldt hevder - at diktningens mytiske billedspråk er den »uunnværlige andre form for verdensåpenbaring og virkelighetsbegrunnelse « som vi trenger ved siden av vitenskapens språk, så skulle ikke bare Gr.s diktning, men også hans tanker om diktningen fremdeles ha bud til oss. Ja, for hörer ikke forståelsen av diktningens vesen med til de filosofiske innsikter som er begrunnet i menneskets grunnstruktur, og som ikke nödvendigvis aksellerer med den teknisk-naturvitenskapelige utvikling? 